\title{
New Sighting of Przewalski Horses
}

$$
\text { By Dr. Z. Kaszab }
$$

In the summer of 1966 Dr Kaszab, Director of the Zoological Department of the Hungarian Natural History Museum in Budapest, was invited by the Mongolian and Hungarian Academies of Science to lead an expedition, his fourth, to western Mongolia, in the course of which the members had the good fortune to sight eight Przewalski wild horses.

SEVERAL species of mammals in the Mongolian People's Republic are now extremely rare and threatened with extinction. They include the Gobi bear Ursus arctos pruinosus Blyth, found in Mongolia only on Kagan Bogd uul (mountain); the wild camel Camelus bactrianus ferus Przewalski, occurring only in the entirely uninhabited Transaltai Gobi, in an area stretching from the eastern foothills of Aj Bogd uul and bounded by the Edrengiin nuruu (chain of mountains, literally 'spine'), and Kagan Bogd uul; the Mongolian beaver Castor fiber birulai Serebrennikov, of which there is only a single population living on the flood plain of the river Bulgan; and, above all, the Przewalski wild horse Equus przewalskii Polyakov, which has aroused keen worldwide interest.

Before 1950, according to Bannikov ${ }^{1}$, the wild horse could still be found frequently between Baitag Bogd uul and the Takhiin Shar nuruu (Yellow Wild Horse range). Garrutt, Sokolow and Salesskaya ${ }^{3}$ state that the last time a wild horse was seen at the Takhiin Shar nuruu was by the Soviet botanist A. A. Yunatov in 1947*. That same year the mare appearing in the Askania Nova records as the brood mare Orlitsa III-Mongol was caught as a filly at Baitak Bogd uul. According to Stubbe ${ }^{5}$ a pregnant mare was seen by Mongolian herdsmen in 1964 , also at Baitag Bogd uul.

Most of the recent literature states that the wild horse occurs only on the mountain ridge between Baitag Bogd uul and the Takhiin Shar nuruu, but that during the last two decades they have decreased to such an extent that expeditions sent specially in search of them have failed to find them ${ }^{1}$, and that the animal can perhaps therefore be considered as extinct even in that area. Despite these accounts, Mongolian experts, particularly Professor Dr A. Dashdorj, remain convinced of the continued existence of the wild horse, and in personal discussions with the author have expressed the view that it can still continue to survive in the almost inaccessible regions of the Jungarian Gobi, undisturbed by man. This I have now confirmed.

In the summer of 1966 I was entrusted with the pleasant and responsible task of leading a two-months expedition in western

- The Mongolian zoologists D. Tsevegmid and A. Dashdorj report that they saw a mare in this region in 1955, reported in ORYX, August 1965. 
Mongolia, under the auspices of the Mongolian and Hungarian Academies of Science. This was my fourth expedition to Mongolia. The route I selected led us in a north-westerly direction through the Takhiin Shar nuruu area, starting from Altai-Somon, a settlement in the south-west part of $\mathrm{Aj}$ Bogd uul.

On June 29 we camped beside an old road, the traces of which are now barely discernible, about three miles south of the pass of the Takhiin Shar nuruu. Next day we set out north-westward, intending, after crossing the mountains, to come out in the valley of the Bij gol (river), or near the Bij-altai settlement the same day. I had a detailed contour map of the area, and without it we should never have succeeded in finding the track as it followed the course (the sair) of driedup river beds. (Sair means ground with damp subsoil.) From our camp-site we managed to reach a small pass, driving our jeep through a ravine by a steep road and thence following an old track to the edge of a deep valley with sides so precipitous that they could not be negotiated by a vehicle. A wide sair extended along the valley. On the top of the smaller sandhills were thriving green shrubs of Tamarix, and one area, densely overgrown with reeds and clumps of Lasiagrostis, showed traces of surface moisture. Along the track leading to the valley we discovered traces of an abandoned herdsmen's camp, an overwintering place excellently protected by rocks with sufficient shelter for several dozen animals-probably used for camels. From here we retraced our steps to the pass, and, after lengthy searching, tracked down the old caravan road, marked on the map, leading up to the plateau of the Takhiin Shar nuruu, which is encircled by high mountains, and ends there in a dry river bed named Tukhumin khundi (hollow), which in places is more than half a mile wide. Against a strong head wind we reached this almost flat plateau, at a height of $6,800 \mathrm{ft}$., and immediately saw, a few kilometres off, a group of animals galloping away from us at full speed. My Mongolian companion, Namkhajdorj Balgan, recognised them at once with the naked eye as Przewalski wild horses, and subsequent observation with a telescope confirmed beyond any possible doubt that this was what they were. For about twenty minutes, we were able to, follow them at a speed of about 25 miles an hour, but were never able to reduce the distance between us. We followed them for about six to eight miles over quite open ground and observed them by telescope until they disappeared. Apart from one animal, they galloped so close to each other at first that, with the unaided eye, we could count only five, but with the telescope we could distinguish eight. A stallion racing at the rear, and separated from the others, occasionally even stopped for an instant. The remaining seven were mares. There were no young animals or foals.

In the dry river bed at the south-east entrance to the Tukhumin khundi we came across further evidence of wild horses in the margin of the sandy, gravelly sair, where there was a quite fresh hoof print and traces of still humid urine discharge from a stallion. I cannot give 
the exact measurements of the hoof print, as we had no measuring instrument, but it was probably about five inches.

Unfortunately I could only take two colour transparencies of the animals galloping on the plateau, one with an ordinary lens, the other with a 4-inch telephoto lens, as these were the only exposures I had left, and all our black and white film had already been used. In the excitement of observing the animals as we pursued them, always hoping that we might get nearer to them, I could not take the time to get a new film from inside the jeep and reload the cameras. The photograph on Plate 2, is the one taken with the telephoto lens.

This chance encounter with Przewalski wild horses was the result of a lucky combination of circumstances. The area is entirely uninhabited and has apparently remained undisturbed for a long time; grazing is infrequent and has never been intensive. Moreover, near the animals' habitat, in depressions of the sair, there are either open drinking places, or at least humid patches with ground water where they can find moisture, and at the start of our trip we saw such a watering place on sair. The strong north-west wind drowned the noise of our jeep's engine as we approached them, and the horses only took to flight when the jeep came into view over the edge of the plateau.

The Przewalski horse has been strictly protected in Mongolia since 1950. Nevertheless, its survival can only be guaranteed if its barren, nearly inaccessible frontier habitat is strictly preserved, with grazing absolutely prohibited and artificial drinking facilities provided at certain places. Furthermore, it is essential to establish the exact habitat of the horses and their numbers between Baitag Bogd uul and the Takhilin Shar nuruu by sending special expeditions to guard the area, make periodic checks and maintain the drinking facilities.

Ergebnisse der Zoologisches Forschungen von Dr. Z. Kaszab in der Mongolei, No. 108.

\section{REFERENCES}

1. BANNIKOV, A. G., 1961. Special natural conditions of the biotope of the Przewalski wild horse and some biological features of this species. Equus, Prague, I: 13-21.

2. DOVTSCHIN (DOVCHIN), N., 1961. The Przewalski horse in Mongolia. Equus, Prague 1: 22-27.

3. GARRUTT, E. W., SOKOLOW (SOKOLOV), I. I., and SALESSKAJA (ZALESKAYA), T. N., 1966. Erforschung und Zucht des PrzewalskiPferdes Equus przewalskii Poljakoff in der Sovietunion. Zeitschr. $f$. Tierzüchtung und Züchtungsbiologie, 82: 377-426.

4. MONTAGU, I., 1965. Communication on the current survival in Mongolia of the wild horse Equus przewalskii, wild camel Camelus bactrianus ferus and wild ass Equus hemionus. Proc. Zool. Soc. London, 144: 425-428, Pl. I.

5. SOKOLOV, I. I., 1959, Perissodactyla and Artiodactyla-Mammalia 1/3 in Fauna SSSR, Nov. Ser. 71, p. 639.

6. STUBBE, M., 1965. Jagd, Jagdgesetz und Wild in der Mongolischen Volksrepublik Ergebnisse der Mongolisch-Deutschen Biologischen Expeditionen seit 1962, No. 6. Beitr. z. Jagd und Wildforschung, Berlin, 4: $163-178$. 